\title{
ВЫСТАВКИ «ИСТОРИЯ В СУДЬБАХ ЛЮДЕЙ» (1990) И «СВЕТ И ТЕНИ ХХ В. ГОМЗИКОВЫ ИСТОРИЯ СЕМЬИ» (2002) КАК ПЕРВЫЙ ОПЫТ МУЗЕЙНОГО ОСВЕЩЕНИЯ «ЗАКРЫТЫХ» ТЕМ
}

\author{
И.А. Пятаева, \\ заведующий, Музей-диорама в Мотовилихе \\ (филиал Пермского краеведческого музея), Пермь \\ diorama-perm@yandex.ru
}

Аннотация. Рассматривается изменение роли музея в культурноисторическом пространстве города - от инструмента идеологической пропаганды к раскрытию «белых пятен» истории и ранее запрещенных тем.

Ключевые слова: музей; идеология; большевики; репрессии; выставка; интеллигенция.

EXHIBITIONS «HISTORY IN THE DESTINIES OF PEOPLE» (1990) AND «LIGHT AND SHADOWS OF THE TWENTIETH

CENTURY. GOMZIKOV'S FAMILY HISTORY «(2002) AS THE FIRST EXPERIENCE OF MUSEUM COVERAGE OF «CLOSED» TOPICS

\author{
I.A. Pyataeva, \\ Head, Museum-Diorama in Motovilikha \\ (branch of the Perm Museum of Local Lore), Perm \\ diorama-perm@yandex.ru
}

Summary. The paper considers the change in the role of the Museum in the cultural and historical space of the city-from an instrument of ideological propaganda to the disclosure of white spots of history and previously forbidden topics of history. tellectuals.

Keywords: Museum; ideology; bolsheviks; repression; exhibition; in-

В советское время музей являлся инструментом идеологической пропаганды. В течение нескольких десятилетий он рассказы- 
вал о том, как с приходом к власти большевиков началась новая счастливая жизнь. Часто желаемое выдавалось за действительное, а правдивые исторические факты умалчивались.

После распада СССР перед сотрудниками «революционного» «Музея-диорамы в Мотовилихе» встала задача переосмысления событий новейшей истории. В 1991 г. окончательно определился новый статус Музея-диорамы как культурно-выставочного центра, в экспозиционных залах которого могут сосуществовать самые разнообразные выставки. Опыт прошедших лет показал, что Музейдиорама стал своеобразной экспериментальной площадкой для апробации актуальных или ранее «закрытых» тем Новейшей истории России. Эти выставки, являясь, безусловно, проблемными, однако охватывали довольно узкий хронологический период: первая четверть XX в. как период революционных потрясений, также были сделаны попытки коснуться темы политических репрессий 30-50-х гг.

В 1990-е - начале 2000-х гг. в экспозиционно-выставочной работе музея темы политической истории России затронуты не в привычном идеологически-пропагандистском ракурсе, а с учетом вновь открывшихся знаний и собранных материалов. Одна за другой появляются выставки, открывающие новые грани отечественной истории: «История в судьбах людей» (1990), «В поисках истины» (1998), «Интеллигенция и революция» (2000), «Свет и тени XX века. Гомзиковы: история семьи» (2002).

Авторы стремились рассказать о сложном трагическом периоде российской истории через судьбы людей. Взглянуть на события XX в. через призму жизни разных поколений. Обращались и к освещению деятельности интеллигенции, роль которой была особенно велика на переломных этапах развития государства. В эпоху крупнейших социальных катаклизмов, когда приходят в движение миллионные массы людей, именно представители интеллигенции формулируют политические программы и лозунги, обосновывают и разъясняют их людям.

Одной из первых попыток переосмысления советской истории стала выставка «История в судьбах людей» (1990). Она была приурочена к 100-летию Пермского краеведческого музея. Авторы описывали историю революционного движения в Прикамье в период 1895-1917 гг., рассказывали о духовной жизни разных социальных слоев населения [3]. 
Выставка «В поисках истины» (1998) подняла тему судьбы пермской интеллигенции первой четверти XX в. В экспозиции были представлены материалы о людях известных и малоизвестных. Мотовилихинский инженер В.Е. Гомзиков, профессор А.Г. Генкель, адвокат М.Н. Наговицын, врач М.Я. Бруштейн. Описывалась их деятельность в создании пермских просветительских и научных обществ, об открытии университета. Отдельной темой был представлен русский авангард 1910-1920-х г. в лице В. Каменского, П. Субботина-Пермяка, пермской мастерской слова «Мы» [2].

Как и везде, среди пермской интеллигенции были те, кто приближал революцию, боролся за нее (врач М.Я. Бруштейн), те, кто возлагал надежды на просветительство (оперный певец А.Д. Городцов, художник А.Н. Зеленин). Были и противники всяких революционных потрясений, например, редактор «Пермских губернских ведомостей» инженер Г.И. Кобяк. Яркими представителями революционного авангарда в искусстве были П.И. Субботин-Пермяк и В.В. Каменский. Вклад провинциальной интеллигенции, врачей, народных учителей, инженеров и служащих в поступательное развитие истории был огромным. На примере одного только города можно было представить глубинные поиски интеллигенции, поиски истины, смысла жизни, путей развития общества.

В 1905 г. в Перми и Мотовилихе просматривались три крупных слоя интеллигенции: область материального производства, область образования и культуры, чиновники различных рангов.

В мае 1905 г. на улицах появилось объявление «От пермского губернатора»: «В предупреждение уличных беспорядков и нарушения общего спокойствия всякого рода сборищи, сходки, шествия по улицам запрещены. Приглашаю жителей Перми не принимать участия в подобных сборищах, во избежание всевозможных опасностей и случайностей, так как может быть пущено в ход огнестрельное оружие» [6].

Что послужило причиной?

Из следственных материалов по делу «О беспорядках в Перми 14-15 мая 1905 года» следует, что в доме Мешкова должно было состояться учредительное собрание местного отделения Всероссийского учительского союза. Неожиданно оно было запрещено губернатором, усмотревшим в программе вопросы политического характера. Недовольство учителей и собравшейся здесь же учащейся мо- 
лодежи переросло в манифестацию в Загородном саду [5]. В списках демонстрантов раскрыт социальный состав участников революционного движения: «Находящихся в сфере наблюдения уже давно было 35 человек, из них 6 рабочих, 29 представителей городской интеллигенции. Из 29: 3 учителя, 10 служащих железной дороги, почты и телеграфа, кустарного и государственного банка, один медик среднего звена, один приказчик книжного магазина Пиотровских, 6 учащихся мужской гимназии и реального училища, 8 не назвали себя».

В дальнейшей помощи революционерам были замечены горные инженеры Пермского пушечного завода С.А. Ильин, P.М. Башкевич, С.В. Белозеров, Н.П. Мякотин, Н.А. Попов, а также врач Александровской больницы. Во время захвата Мотовилихинского завода в декабре 1905 г. большевиками в беспорядках принимали участие инженерно-технические работники А.Е. Безсонов, А.Г. Дябин, А.Я. Соколов, Н.Н. Серовиков. По агентурным сведениям: в рабочую дружину входил фармацевт Мотовилихинской казенной аптеки П.П. Попцов, врач-дантист Х.Я. Усискин. Оказывали помощь раненым врачи заводской больницы Д.А. Соловьев, Баранов, Ф.А. Кестранек, земский врач М.Я. Бруштейн [1].

После декабрьского восстания 1905 г. в Мотовилихе губернатором были запрещены собрания, сходки, шествия и демонстрации. Была закрыта либеральная газета «Пермский край». По «Делу о стрельбе в Мотовилихе» было арестовано 101 человек (на 30 \% интеллигенция). Тюремный инспектор докладывал о раздельном содержании в тюрьме рабочих и интеллигенции. К двум годам крепости был приговорен врач В.М. Здравомыслов, редактор газеты «Камский край». Среди осужденных были учителя П.А. Матвеев М.П. Федорова А.Н. Ягодникова Л.Н. Сюзев, В.С. Мутных, присяжный поверенный В.Н. Трапезников, инженерно-технические служащие А.Я Соколов, Н.Н. Серовыиков, А.Г. Дябин, А.А. Ахлюстин, агроном В.А. Владимирский, гимназист А.В. Семченко и другие [4].

Выставка «Свет и тени XX века. Гомзиковы: история семьи» (2002) стала еще одной попыткой музейщиков переосмыслить события XX в. В экспозиции прослеживалось желание подытожить его основные события, выделить среди них те, которые оказали наибольшее влияние на судьбу страны, народа. Авторы взглянули 
на $\mathrm{XX}$ в. сквозь историю типичной рядовой семьи, примером которой можно считать семью Гомзиковых из Мотовилихи. Жизнь каждого из ее членов - яркая иллюстрация определенного этапа жизни страны, современниками которого они были. Среди них и революционер, и репрессированный, и участники Великой Отечественной войны. Кроме того, глава семьи В.Е. Гомзиков - фигура «знаковая» для Мотовилихи: он автор памятника Борцам революции на Вышке, который долгое время был символом района, изображение памятника являлось основой герба города Перми социалистического периода.

Обращаясь к основным моментам истории страны и истории типичной мотовилихинской семьи, авторы попытались отразить такие проблемы, как соотношение личного и общественного в разные периоды истории страны, влияние государства на личную жизнь, на семью как ячейку общества, выявить внутренние духовные устои семьи. Впервые музей открыл уникальную выставку, где показана жизнь разных поколений одной семьи на протяжении столетия [8].

Тема выставки охватывает XX в., начиная с событий Первой русской революции, участником которой был Василий Евлампиевич Гомзиков - глава семьи. Он обладал многими дарованиями: в свободное время плотничал, хорошо рисовал, писал стихи, играл на мандолине. Его жена Агния была дочерью священника. У них было трое сыновей: Валериан, Юлий, Игорь. На фоне основных событий XX в. разворачивается история обычной, но по-своему уникальной семьи Гомзиковых, чьи предки поселились в Мотовилихе более 200 лет назад. В 30-е гг. ХХ в. «жили бедно, но бедности этой как-то не замечали. В доме все постоянно переставлялось, менялось. Вся мебель была сделана руками Василия Евлампиевича. Читали много. Брали в библиотеке все толстые литературные журналы» [2].

Василий Евлампьевич Гомзиков родился 22 марта 1884 г. в семье столяра Мотовилихинского завода. Евлампий Гомзиков приложил все силы к тому, чтобы дать образование единственному сыну: в семь лет тот поступил в Мотовилихинскую земскую школу, затем в Мотовилихинское двухклассное министерское училище. Далее, в 1898-1901 гг., в Пермское техническое железнодорожное училище. 
В январе 1904 г. Василий Гомзиков увлекся революционной деятельностью. Он помогал лидеру большевиков Александру Борчанинову в составлении и печатании листовок. Работа шла успешно, но в марте по доносу провокатора оба были арестованы. В тюрьме появилась подпольная кличка - Лампыч. После освобождения в июне началась активная подпольная работа. Гомзиков участвовал в митингах и демонстрациях. В ноябре 1905 г. Василий Гомзиков исчез из дому, чтобы избежать службы в армии. Он был арестован в январе 1906 г. в Воронеже и в мае этапирован в Пермь. 10 июня поступил в распоряжение пермского уездного воинского начальника, так как подлежал призыву еще в 1905 г. Таким образом, Василий Гомзиков не принимал участия в декабрьских революционных событиях в Мотовилихе [7].

К 1909 г. закончилась служба в армии, Василий Гомзиков поступил служащим Пермской железной дороги, откуда в мае был уволен как политически неблагонадежный. Дальнейший политический путь Гомзикова в источниках представлен довольно размыто, в какой-либо активной революционной борьбе он не упоминается.

Октябрьскую революцию Гомзиков встретил в Перми. Однако, участвуя в национализации частных предприятий, он усомнился в правильности террористических методов, которые применяли большевики. Гомзиков покинул партию 1918 г. Советские летописцы оправдывали его поступок вспыльчивым характером. Убеждали, что каких-либо принципиальных разногласий с политикой партии у Василия Евлампиевича не было: «Будучи честным человеком, он потом строго осудил свой поступок и тяжело его переживал. Однако вступить вновь в ряды партии не счел для себя возможным, так как в тяжелый год посмел выйти из нее» [7].

Отойдя от революционной и политической деятельности, в 1919-1940 гг. Василий Гомзиков работал на Мотовилихинском заводе техником-чертежником, а затем конструктором. Он навсегда вошел в историю Перми и Мотовилихи как автор памятника «Павшим борцам революции» и основатель историко-революционного мемориала на Вышке. 


\section{Список литературы и источников}

1. Бушмаков А.В. Пермь и пермяки [Электронный ресурс]. URL: http: //archive.perm.ru/projects/articles-and-publications/1116128perm-and-perm-in-1905/ (дата обращения: 10.08.2019).

2. Выставка «В поисках истины»: тематико-экспозиционный план // Научно-ведомственный архив ГКБУК «Пермский краеведческий музей». Пермь, 1998.

3. Выставка «История в судьбах людей»: тематико-экспозиционный план // Научно-ведомственный архив ГКБУК «Пермский краеведческий музей». Пермь, 1990.

4. Дело о стрельбе в Мотовилихе // ГАПК. Ф. 160. Оп. 1. Д. 50.

5. Кириллов Б.П. Рассказы о Мотовилихе. Пермь: Пушка, 1998. 128 c.

6. Полицейский отчет о забастовках в Мотовилихе [Электронный ресурc]. URL: https://uncle-ho.livejournal.com/129263.html (дата обращения: 07.07.2019).

7. Революционеры Прикамья. 150 биографий деятелей революционного движения, работавших в Прикамье / под ред. Н.А. Аликиной, И.Г. Горовой. Пермь: Перм. кн. изд-во, 1966.

8. Экскурсия по выставке «Свет и тени XX века. Гомзиковы: история семьи»: текст // Научно-ведомственный архив ГКБУК «Пермский краеведческий музей». Пермь, 2002. 